\title{
Trophic structure and biomagnification of mercury in an assemblage of deepwater chondrichthyans from southeastern Australia
}

\author{
H. Pethybridge ${ }^{1,4,5, *}$, E. C. V. Butler ${ }^{2}$, D. Cossa ${ }^{3}$, R. Daley $^{2}$, A. Boudou ${ }^{5}$ \\ ${ }^{1}$ IMAS, University of Tasmania, Private Bag 77, Hobart, Tasmania 7001, Australia \\ ${ }^{2}$ Ultramarine Concepts, PO Box 476, Sandy Bay, Tasmania 7006, Australia \\ ${ }^{3}$ IFREMER, Centre de Méditerranée, BP 330, 83507 La Seyne-sur-Mer, France \\ ${ }^{4}$ CSIRO Marine and Atmospheric Research, GPO Box 1538, Hobart, Tasmania 7001, Australia \\ ${ }^{5}$ Université de Bordeaux, 33405 Talence Cedex, France
}

\begin{abstract}
Stable isotope ratios of carbon $\left(\delta^{13} \mathrm{C}\right)$ and nitrogen $\left(\delta^{15} \mathrm{~N}\right)$ were used to evaluate trophic structure and mercury biomagnification in an assemblage of 16 deepwater chondrichthyans (primarily, 2 squaliformes: Centroselachus crepidater and Etmopterus baxteri) collected from continental waters off southeastern Australia from 2004 to 2006. In all species, mean trophic position (TP; quantified by $\delta^{15} \mathrm{~N}$ ) ranged from 3.5 to 4.7 (indicative of tertiary consumers). Minor variation in $\delta^{13} \mathrm{C}$ enrichment was observed between species $(-18.7$ to $-17.1 \%$ ) with the exception of Squalus acanthias $\left(-19.3 \pm 0.1 \%\right.$ ). Total mercury (THg) levels ranged from 0.3 to $4.5 \mathrm{mg} \mathrm{kg}^{-1}$ (wet mass, wm) with the highest concentrations correlated with increasing individual size and TP. Using published (TP and THg) data on low-mid trophic prey groups collected from the study area, THg biomagnification factors between selected predator-prey associations and trophic magnification factors (TMF) within various assemblage and community groupings were calculated. As an assemblage, deepwater elasmobranchs demonstrated moderate rates of THg biomagnification, as indicated by the regression slope (0.69 TP giving a TMF of 4.8) while higher rates were reported in the extended continental shelf/slope community (1.13 TP giving a TMF of 13.4). Among-system differences in TMF were found between low-mid and mid-high order food chains as well as between shelf/upper-slope, mid-slope, and benthic food webs, signifying that bioaccumulation pathways are closely related to physical-chemical (bathome affinity) and community (presumably species composition and food chain length) structure.
\end{abstract}

KEY WORDS: Hg · Biomagnification - Trophic transfer $\cdot$ Deep-sea $\cdot$ Elasmobranchs $\cdot$ Stable isotopes

Resale or republication not permitted without written consent of the publisher

\section{INTRODUCTION}

Understanding trophic ecology, i.e. feeding relationships among organisms, is paramount for informed ecosystem-based management decisions, including decisions that concern the biotransfer of contaminants that are harmful to predators and affect human health (Burger et al. 2007, Choy et al. 2009). Although traditional stomach content analysis offers taxonomic precision in feeding data, gathering such data is not always logistically feasible or essential. This is particularly true for deep-sea communities where remoteness creates high logistical costs, and specimens frequently loose their ingesta during capture and retrieval to the surface (Drazen et al. 2008). For deepwater chondrichthyans, these problems are further compounded because many populations have been depleted in the Indian, Atlantic and Pacific 
Oceans (Graham et al. 2001). These species will be slow to recover, due to late age at maturity and low fecundity (Kyne \& Simpfendorfer 2010); therefore collection contravenes conservation objectives (Daley et al. 2002).

Although coarse in taxonomic resolution, analyses of natural stable isotope ratios of carbon $\left(\delta^{13} \mathrm{C}\right)$ and nitrogen $\left(\delta^{15} \mathrm{~N}\right)$ are increasingly being applied to a suite of marina biota as a relatively quick, logistically and ethically viable tool to quantitatively assess energy flows in food webs (Peterson \& Fry 1987), time-integrated food-web structure (Post 2002), and spatiallyintegrated patterns of assimilated organic substrates (Hobson 1999). The approach is based on the fact that $\delta^{15} \mathrm{~N}$ shows a systematic mean enrichment (typically around $3.4 \%$ ) with each increasing trophic position (Minagawa \& Wada 1984); and consequently, relative trophic positions can be estimated (Post 2002). In contrast, $\delta^{13} \mathrm{C}$ remains relatively unaffected by trophic transfer (Fry \& Sherr 1984) and can instead be used to indicate foraging location due to differences between aquatic vs. terrestrial, nearshore vs. offshore, or pelagic vs. benthic baseline carbon contributions (Hobson et al. 1995, Vaudo \& Heithaus 2011).

Mercury (Hg), similar to other persistent environmental contaminants (cadmium and polychlorinated biphenyls) is assimilated (following bacterially mediated methylation for $\mathrm{Hg}$ ) primarily via dietary intake (Cabana \& Rasmussen 1994, Wiener et al. 2003), and thereafter, biomagnifies up food chains. As this phenomenon depends on the structure and complexity of the food web (Wang 2002), stable isotopes have been suitably coupled with contaminant analysis to delineate bioaccumulation patterns in marine food webs (Atwell et al. 1998, Power et al. 2002) and better understand the extent of biomagnification in top-order predators, including sharks (Fisk et al. 2002, Domi et al. 2005, Newman et al. 2011). Mercury in its most toxic form, monomethylmercury (MeHg), continues to draw a great deal of scientific and policy interest (Selin 2011) largely due to its harmful health effect (Eisler 2006) and its long-ranging atmospheric transport and global distribution (Mason et al. 1995). Thus, even in relatively pristine environments $\mathrm{Hg}$ can be of local concern, making its monitoring fundamental to the evaluation of risk to the environment and human health.

The continental shelf and slope waters off southeastern Australia support a number of commercially important species. The mid-slope (600-2000 m) demersal fishes comprise an identifiable community that supported a major commercial trawl fishery for orange roughy (Hoplostethus atlanticus, Trachichthyidae), and oreo dories (Oreosomatidae) for more than 20 yr until it was largely closed due to overfishing in 2006 (Larcombe \& Begg 2007). The major bycatch was a guild of benthopelagic squaliformes (mainly Somniosidae, Etmopteridae) that feed on fish and squid and dominate the mid-upper trophic positions, probably as top-down predatory regulators of community dynamics (Bulman et al. 2002, Hallett \& Daley 2011). A minor bycatch was a guild of chimaeras (Chimaeridae, Rhinochimaeridae) with specialised beak-like dentition suitable for crushing shelled benthic prey (Last \& Stevens 2009). The trophic and community structures in upper-slope (200-600 m) waters in the same region are not as well defined. An assemblage of commercial teleosts such as pink ling (Genypterus blacodes) and ocean perch (Helicolenus barathri) co-occur with bycatch chondrichthyans. A number of shark species that complete much of their life history on the continental shelf and are not entirely dependent on slope food webs are also present occasionally.

Upper- and mid-slope chondrichthyans that occur off southeastern Australia are known to accumulate MeHg concentrations that exceed those established by community legislation ( $>1 \mathrm{ppm}$; Pethybridge et al. 2010a). There are concerns that consumption of these species and others harvested from the same community assemblages will affect human health. Despite this, knowledge of deepwater chondrichthyan feeding habits and contaminant bioaccumulation pathways in continental-shelf and slope waters is limited. In this study, we use $\delta^{13} \mathrm{C}$ and $\delta^{15} \mathrm{~N}$ data to explore the trophic structure and biomagnification of $\mathrm{Hg}$ in an assemblage of 16 deepwater chondrichthyan species occurring around the continental shelves/slopes and seamounts off southeastern Australia. Specifically, these data are analysed using regression models to estimate trophic positions, trophic magnification factors within various food web community assemblages, and biomagnification factors between specific predator-prey pairs. These data will provide (1) the means to improve current ecosystem models; (2) a greater understanding of the trophic transfer and bioavailability of mercury in this and other continental shelf/slope food webs; and (3) important baseline information for subsequent comparative studies on these and other deepwater chondrichthyan species, worldwide.

\section{MATERIALS AND METHODS}

Specimens were collected from the continental slope around eastern and southern Tasmania, and 
southwest off Victoria, between 2004 and 2006 (Fig. 1). Species were identified based on Last \& Stevens (2009) and were grouped according to their principle bathome: shelf, upper slope, or mid slope (see Table 1). Most mid-slope specimens were taken by commercial operators targeting orange roughy with otter trawl nets (90-110 mm stretched mesh) in waters deeper than $600 \mathrm{~m}$. Shelf and upper slope species were mainly caught by commercial auto longlining vessels targeting pink ling in waters (200-600 m) off Tasmania using 12/0 Mustad hooks baited with squid.

Two subsamples of $100 \mathrm{~g}$ of muscle tissue (obtained posterior to the dorsal fin) were collected from each specimen and stored in polyethylene ziplock bags at $-20^{\circ} \mathrm{C}$. All homogenous tissue samples were freeze dried $\left(-80^{\circ} \mathrm{C}\right.$ for up to $\left.60 \mathrm{~h}\right)$ and ground to fine powder (mesh size 100-200 $\mu \mathrm{m}$ ) with a mortar and pestle. Lipids were not removed, because lipid content in the muscle tissue of these species is low $(<1.0 \%$, Pethybridge et al. 2010b).

Carbon, nitrogen, isotopic carbon $\left(\delta^{13} \mathrm{C}\right)$ and nitrogen $\left(\delta^{15} \mathrm{~N}\right)$ were analysed simultaneously using a continuous flow isotope-ratio mass spectrometer (CF-IRMS). Stable isotope ratios are expressed as delta values $\left(\delta^{13} \mathrm{C}, \delta^{15} \mathrm{~N}\right)$ and measured as parts per thousand differences (\%) relative to ANU sucrose and atmospheric $\mathrm{N}$ (air) for isotopes $\delta^{13} \mathrm{C}$ and $\delta^{15} \mathrm{~N}$, respectively. Replicated measurements of internal laboratory standards (Acetanilidae) and working standards (prawns) gave precision errors of \pm 0.1 and $\pm 0.2 \%$ for $\delta^{15} \mathrm{~N}$ and $\delta^{13} \mathrm{C}$, respectively. $\mathrm{C}: \mathrm{N}$ ratios were $<3.5$ indicating that tissues were mostly composed of protein (Hoffman \& Sutton 2010) and validates not performing lipid extraction of tissues.

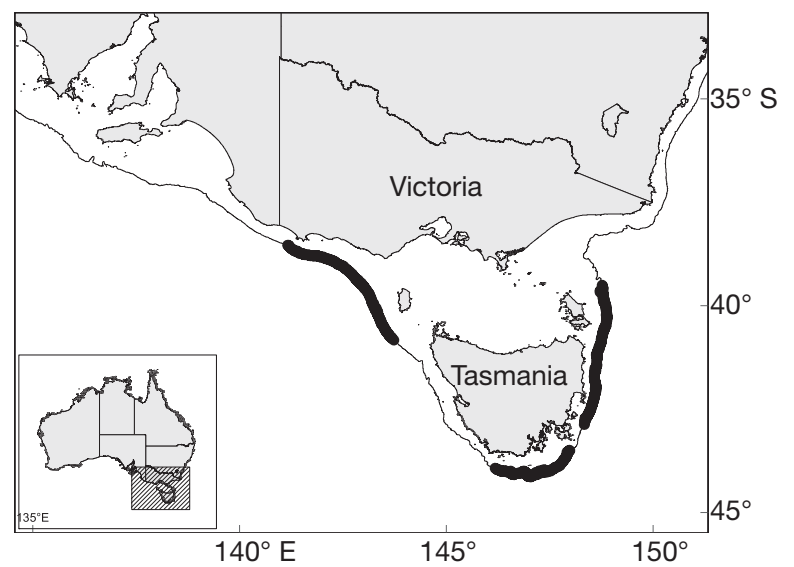

Fig. 1. Collection area. Contour line indicates depth of $400 \mathrm{~m}$ and black thickened line indicates capture locations
Trophic position (TP) of chondrichthyan species was estimated from $\delta^{15} \mathrm{~N}$ values following the equation (after Cabana \& Rasmussen 1994):

$$
\mathrm{TP}=\left(\delta^{15} \mathrm{~N}_{\text {shark }}-\delta^{15} \mathrm{~N}_{\text {phyto }}\right) / 3.4+1
$$

$\delta^{15} \mathrm{~N}_{\text {shark }}$ is the mean nitrogen isotopic ratio of the shark species, while $\delta^{15} \mathrm{~N}_{\text {phyto }}$ is that of marine phytoplankton and particulate organic matter (POM), which was assumed to be $4.1 \%$.

This value has been derived from baseline $\delta^{15} \mathrm{~N}$ reported in outer continental shelf waters off southeast Australia (2.3 to $8.4 \%$, Davenport \& Bax 2002) and taken relative to published trophic position data (base on stomach content analysis) reported for primary consumers from the same continental midslope ecosystem as our study (Bulman et al. 2002). We have taken $3.4 \%$ as the mean nitrogen fractionation between 2 trophic positions (Minagawa \& Wada 1984 ; and reviewed by Post 2002). A biplot of $\delta^{13} \mathrm{C}$ vs. $\delta^{15} \mathrm{~N}$ data was used to characterize the trophic structure of the chondrichthyan assemblage and allowed us to explore dietary breadth in Centroselachus crepidater and Etmopterus baxteri using summary matrices (after that used by Vaudo \& Heithaus 2011) in which the total convex hull area of the $\delta^{13} \mathrm{C}-\delta^{15} \mathrm{~N}$ polygon encompassing all individuals was calculated.

Speciation analysis of mercury (reported in Pethybridge et al. 2010a) demonstrated that $\geq 91 \%$ of $\mathrm{THg}$ was present as methylmercury ( $\mathrm{MeHg}$ ) in the white muscle tissue of most documented shark species; and thus, THg was deemed an appropriate measure of the more toxic MeHg. Analyses of total mercury (THg) were carried out on 2 to 3 replicate samples ranging from 10 to $50 \mathrm{mg}$ of dried muscle tissue. THg concentrations were determined by flameless atomic absorption spectrometry using an Advanced Mercury Analyser AMA 254 (Altec, Prague), with greater detail reported in Cossa et al. (2002). The accuracy and the reproducibility of the method were established using an international certified standard (DORM-2, National Research Council Canada) with certified values reproduced within confidence limits (up to $95 \%$ ) and a detection limit of $0.007 \mathrm{mg} \mathrm{kg}^{-1}$. $\mathrm{THg}$ concentrations are reported in $\mathrm{mg} \mathrm{kg}^{-1}$, as total $\mathrm{Hg}$ per wet mass (wm), using calculations of total water content of the muscle tissue (mass difference before and after freeze-drying) for conversion from dry to wet mass.

To examine potential $\mathrm{Hg}$ exposure routes and bioaccumulation pathways in extended food chains, we used published mercury (Pethybridge et al. 2010c) and trophic position data (calculated by 
stomach content analysis as in Bulman et al. (2002) and/or quantified using $\delta^{15} \mathrm{~N}$ reported by Davenport \& Bax 2002) for 10 mid-trophic prey groups found within the study area and commonly observed in the diet of multiple chondrichthyans analysed here (Bulman et al. 2002, Daley et al. 2002, Pethybridge et al. 2011). Specifically, we use $\delta^{15} \mathrm{~N}$ and $\mathrm{THg}$ data for 2 low-trophic (zooplankton and crustaceans) and 6 mid-trophic (2 cephalopod and 6 fish) groups classified by their habitat affinity (mesopelagic, bathypelagic and benthic) and dominant feeding strategy (omnivore, piscivore and invertivore/zooplanktivore). This also included individual data for 3 abundant mesopelagic fish species; redbait Emmemichthys nitidis, Hector's lanternfish Lampacnyctodes hectoris and cardinalfish Epigonus lenimen.

To examine the extent in which mercury biomagnifies throughout the food web, we have calculated biomagnification factors (BMF) between various prey and chondrichythyan species/groups and the trophic magnification factors (TMF) within the entire study assemblage (chondrichthyans) and extended community (entire food web). Such factors have been applied to a number of whole ecosystem studies (e.g. Atwell et al. 1998, Campbell et al. 2005, Jæger et al. 2009) and separately for a group of higher-order predators (e.g. fish: Power et al. 2002; seabirds: Hop et al. 2002) using the following equations:

$$
\begin{gathered}
\mathrm{BMF}=\left([\mathrm{THg}]_{\text {predator }} /[\mathrm{THg}]_{\text {prey }}\right) /\left(\mathrm{TP}_{\text {predator }}-\mathrm{TP}_{\text {prey }}\right) \\
\mathrm{TMF}=10^{b}
\end{gathered}
$$

with $b$ taken as the slope in the equation $\log (\mathrm{THg})=$ $a+b \mathrm{TP}+e$, where $a$ is the intercept, $b$ is the slope and $e$ is the error estimate. TPs in both BMF and TMF equations are based on that quantified by $\delta^{15} \mathrm{~N}$ as per Eq. (1).

Due to constraints of our sample size, inter-annual or gender-related differences in THg levels, $\delta^{15} \mathrm{~N}$ and $\delta^{13} \mathrm{C}$ isotopes were not investigated. Furthermore, due to limited sample replication for each species, statisti$\mathrm{cal}$ analyses were only performed on squaliformes $E t$ mopterus baxteri and Centroselachus crepidater (with sample sizes $\geq 20$ ). To assess relationships within an assemblage of chondrichthyans, species were pooled together for statistical analyses. Linear regression models were used to examine relationships between THg and length, $\delta^{15} \mathrm{~N}$, TP and $\delta^{13} \mathrm{C}$, and standardized regression coefficients were used to infer the relative importance of each independent variable for explaining variations in the dependent variable. Analysis of variance (ANOVA with Dunnett-Tukey-Kramer pair- wise multiple comparison test) were undertaken to establish respective significant differences within the dataset. All the statistical analyses were performed using SPSS software.

\section{RESULTS}

\section{Trophic structure of the chondrichthyan assemblage}

Carbon and nitrogen stable isotopes $\left(\delta^{13} \mathrm{C}, \delta^{15} \mathrm{~N}\right)$, $\mathrm{C}: \mathrm{N}$ ratios and total mercury (THg) concentrations varied between the 16 species of demersal chondrichthyans analysed (Table 1). $\delta^{15} \mathrm{~N}$ values for all species assessed ranged from 12.4 to $16.6 \%$ demonstrating diversity in trophic positions, with southern dogfish Centrophorus zeehaani $(\mathrm{n}=2$ ) having the highest mean nitrogen enrichment and trophic position $\left(\delta^{15} \mathrm{~N}=16.5 \pm 0.1 \%\right.$, TP $\left.=4.7\right)$, followed by the broadnose sevengill shark Notorynchus cepedianus $(\mathrm{n}=1)(15.4 \%$; TP $=4.4)$. Freckled catshark Apristurus sinensis $(\mathrm{n}=1)$ and Etmopterus baxteri $(\mathrm{n}=20)$ had the lowest $\delta^{15} \mathrm{~N}$ ratios and trophic positions $(12.9 \%$; $\mathrm{TP}=3.8$, and $13.5 \pm 0.27 \%$; $\mathrm{TP}=3.8$, respectively). Adult Centroselachus crepidater, piked spurdog Squalus megalops, Owston's dogfish Centroscymnus owstoni and kitefin shark Dalatias licha all showed intermediate $\delta^{15} \mathrm{~N}$ values (13.5 to $15.3 \%$ ) and trophic positions (3.9 to 4.4). When all chondrichthyans were pooled, total length (TL) was significantly correlated with $\delta^{15} \mathrm{~N}\left(\mathrm{R}^{2}=0.45, \mathrm{p}<0.001\right)$. For the 2 species with large enough sample sizes $(>20)$ for statistical treatment, a strong correlation between TL and $\delta^{15} \mathrm{~N}$ was observed in C. crepidater $\left(\mathrm{R}^{2}=0.64\right)$ with a weaker correlation for E. baxteri $\left(\mathrm{R}^{2}=0.28\right)$. Furthermore, in C. crepidater significantly higher $\delta^{15} \mathrm{~N}$ values were recorded in adults (63 to $91 \mathrm{~cm} \mathrm{TL}$ ) compared to juveniles ( 34 to $47 \mathrm{~cm} \mathrm{TL}$ ) with a mean difference of $1.2 \%$ o $(p=0.01)$. Thus, trophic position seems to increase with shark size both among and within a species.

$\delta^{13} \mathrm{C}$ values varied within a small range $(-19.3$ to $-17.1 \%$ ). Mean $\delta^{13} \mathrm{C}$ values were most depleted for piked dogfish Squalus acanthias, S. megalops and Etmopterus baxteri $(-19.3,-18.8,-18.7 \%$, respectively) and most enriched for Portuguese dogfish Centroscymnus coelopsis, Centroselachus crepidater, and Chimaera lignaria (-17.1, $-17.4,-17.4 \%$, respectively). Although not significant, $\delta^{13} \mathrm{C}$ in $C$. crepidater showed some correlation with $\mathrm{TL}\left(\mathrm{R}^{2}=\right.$ $0.19, p=0.064$ ). Bathome affinity (shelf vs. upper- vs. mid-slope) affected $\delta^{13} \mathrm{C}\left(F_{2,64}=8.08, \mathrm{p}=0.01\right)$ where 
Table 1. Range (min/max) of total length (TL, in $\mathrm{cm})$, total mercury $\left(\mathrm{THg}\right.$, in $\left.\mathrm{mg} \mathrm{kg}^{-1} \mathrm{wm}\right)$, carbon $\left(\delta^{13} \mathrm{C}\right)$, and nitrogen $\left(\delta^{15} \mathrm{~N}\right)$ isotopic composition (\%o) in muscle tissue and estimated trophic position (TP; see Eq. 1) for 16 demersal shark species collected along the continental slope of southeastern Australia. $\mathrm{N}=$ sample size; F:M = sex ratio, females:males

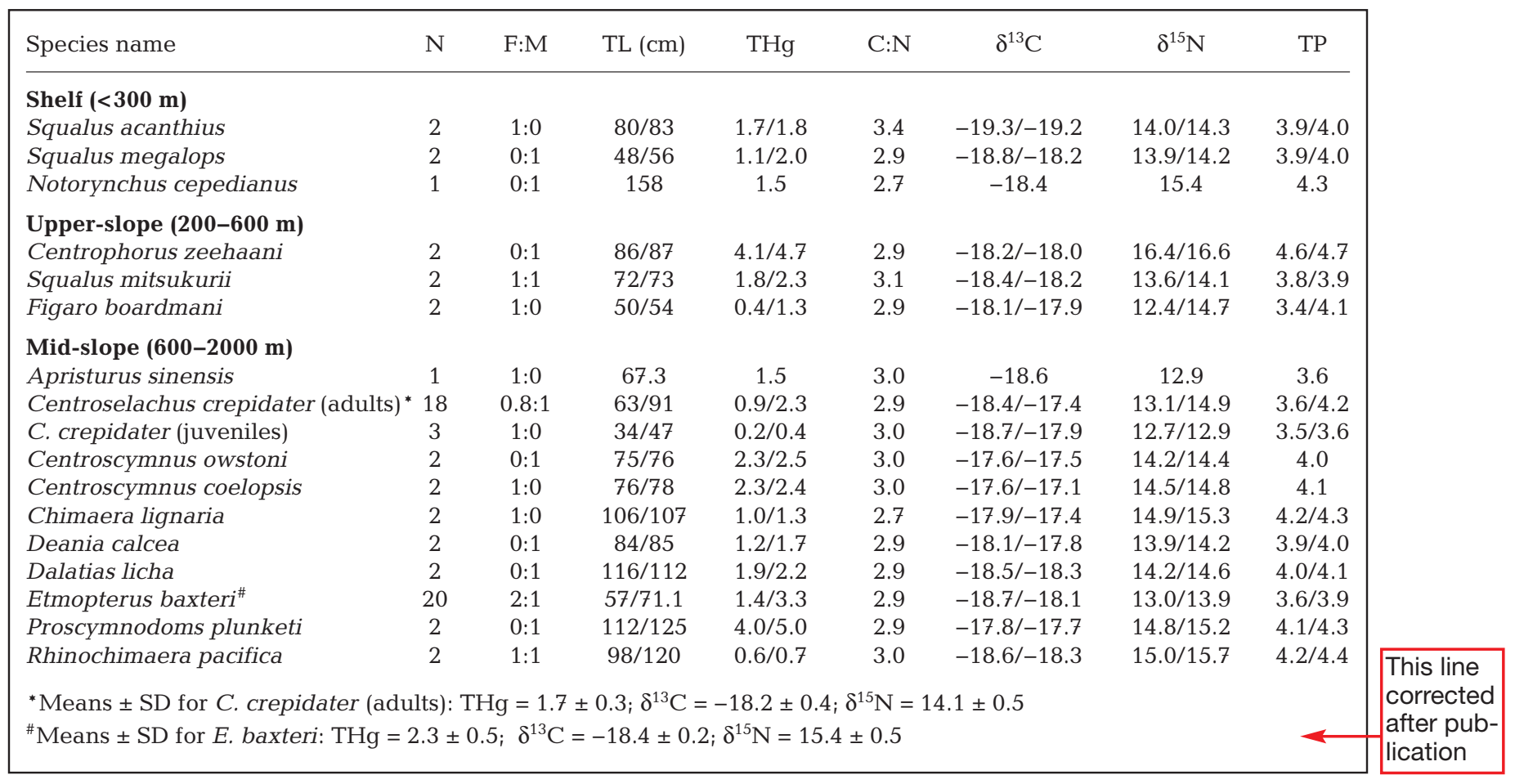

shelf species significantly differed from slope (both upper and mid) species. However, no effect of bathome on $\delta^{15} \mathrm{~N}$ was demonstrated $\left(F_{2,64}=2.75, \mathrm{p}=0.71\right)$.

A visual characterisation of the chondrichthyan food web structure was achieved by plotting $\delta^{15} \mathrm{~N}$ (trophic position) against $\delta^{13} \mathrm{C}$ (carbon source, Fig. 2A). A significant correlation between $\delta^{13} \mathrm{C}$ and $\delta^{15} \mathrm{~N}$ was displayed for Centroselachus crepidater $\left(\delta^{15} \mathrm{~N}=1.3 \delta^{13} \mathrm{C}+36.9, \mathrm{R}^{2}=0.43, \mathrm{p}=0.02\right)$, and in pooled species groups, but not in Etmopterus baxteri $\left(R^{2}=0.06, p=0.24\right.$, Table 2). Using the same biplot and summary matrices, the dietary niche breadth of adult individuals of $C$. crepidater and E. baxteri was found to be 1.13 and 0.82 units $^{2}$, respectively. For $C$. crepidater and E. baxteri, 27 and $41 \%$, respectively, of their stable isotope niche spaces overlapped (Fig. 2A). The largest quantitative interspecific differences of both $\delta^{13} \mathrm{C}$ and $\delta^{15} \mathrm{~N}$ values were observed between Centrophorus zeehaani and Squalus acanthias (Table 1).

\section{THg concentrations and biomagnification}

Total mercury (THg) concentrations in the muscle tissue of the various species of sharks varied by more than one order of magnitude: from 0.3 to $4.51 \mathrm{mg}$ $\mathrm{kg}^{-1}$ (wm) (Table 1). Highest concentrations were observed in Plunket's shark Proscymnodon plunketi (4.49 $\left.\pm 0.5 \mathrm{mg} \mathrm{kg}^{-1}, \mathrm{wm}\right)$, which included the 2 largest individuals assessed (112 and $125 \mathrm{~cm}$ TL). The lowest levels of mercury were recorded in juvenile Centroselachus crepidater $\left(0.3 \pm 0.1 \mathrm{mg} \mathrm{kg}^{-1}\right.$, wm) and in adults of Rhinochimaera pacifica and sawtail catshark Figaro boardmani $(0.63 \pm 0.1$ and $0.81 \pm 0.4 \mathrm{mg} \mathrm{kg}^{-1}, \mathrm{wm}$, respectively). Among pooled chondrichthyan groups, bathome (shelf vs. upper slope vs. mid-slope) did not seem to influence THg concentrations $\left(F_{2,64}=1.24, \mathrm{p}=0.29\right)$.

When sharks only were analysed (chimaeras excluded), log-transformed $\mathrm{THg}$ levels correlated strongly with $\delta^{15} \mathrm{~N}\left(\mathrm{R}^{2}=0.33, \mathrm{p}<0.01\right)$, less with length $\left(R^{2}=0.21, p=0.04\right)$ and not at all with $\delta^{13} C$ $\left(\mathrm{R}^{2}=0.01, \mathrm{p}=0.50\right.$; Table 2$)$, suggesting that $\delta^{15} \mathrm{~N}$ quantified trophic positions are the best proxies for mercury biomagnification in shark assemblages. However, interspecific differences were evident with comparatively different trends in THg biomagnification observed between the 2 sympatric (mid-slope) squaliformes Centroselachus crepidater and Etmopterus baxteri (Tables $2 \& 3$ ). Most notably, lower THg biomagnification rates were reported in E. bax- 

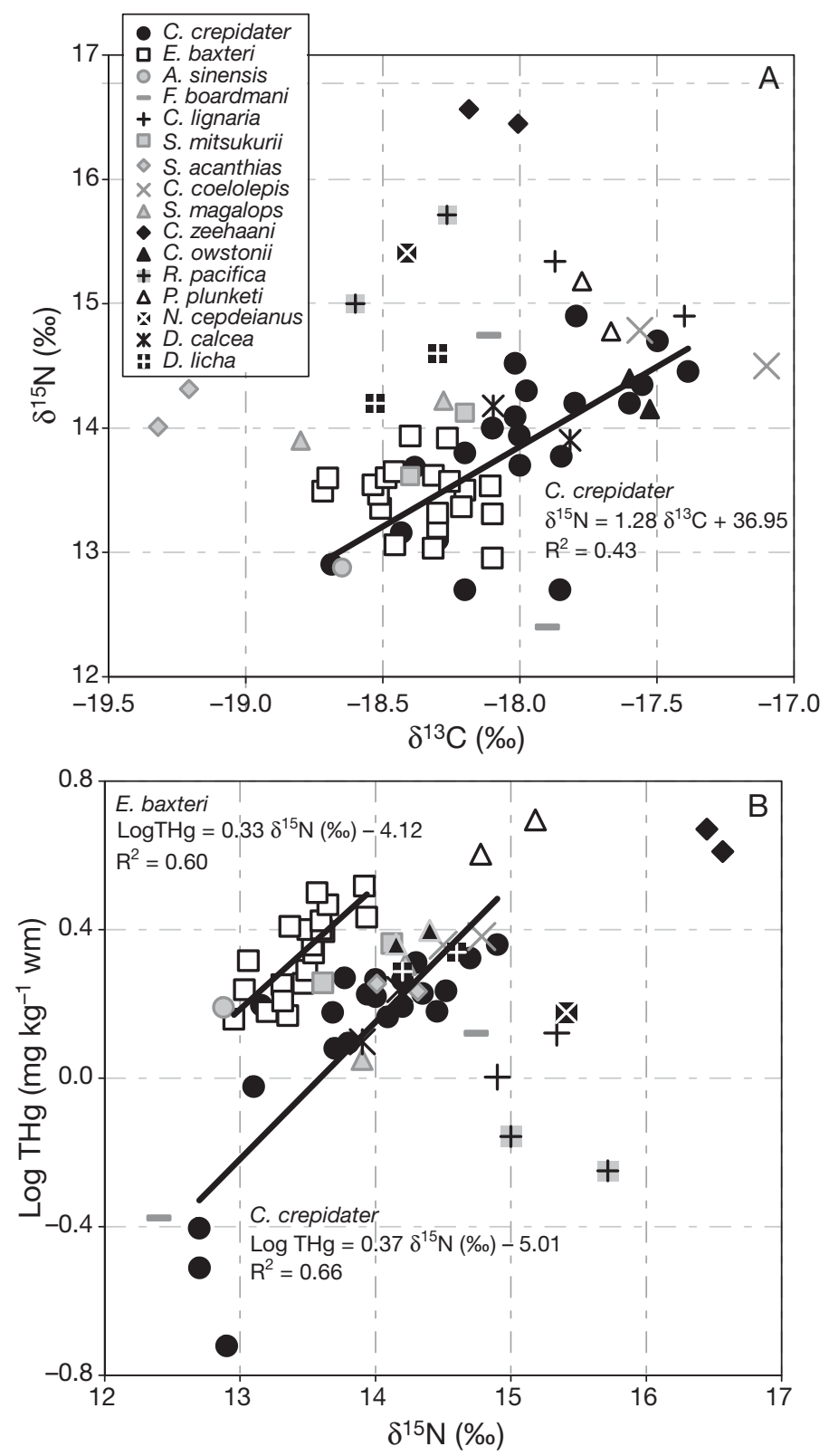

Fig. 2. Regression relations between (A) stable isotopic carbon $\delta^{13} \mathrm{C}$ and trophic position (quantified by $\delta^{15} \mathrm{~N}$ ), and (B) $\delta^{15} \mathrm{~N}(\%)$ and total mercury as $\log \left(\mathrm{THg}, \mathrm{mg} \mathrm{kg}^{-1} \mathrm{wm}\right)$ for all 16 deepwater chondrichthyans analysed in this study. Refer to Table 1 for names of genera

teri where the slope $(b=0.33)$ of the linear regression model for $\log (\mathrm{THg})$ and $\delta^{15} \mathrm{~N}$ was less than that for $C$. crepidater $(b=0.37)$ (Fig. 2B). Similarly, the slope for the $\log (\mathrm{THg})$-TL model was lower for $E$. baxteri than for $C$. crepidater $(b=0.008$ and 0.015 , respectively, Table 2). An almost significant relationship between THg and $\delta^{13} \mathrm{C}$ was observed in C. crepidater $\left(\mathrm{R}^{2}=\right.$ $0.24, \mathrm{p}=0.06$, Table 3 ) but not in E. baxteri or in pooled-species groups ( $p>0.1$, Table 2$)$. Thus, it seems evident that biomagnification of THg in sharks is connected to intra- and inter-specific ontogenetic (size and development-related) differences in feeding behavior, mostly attributed to an individual's trophic position.

Biomagnification factors (BMF) calculated for Etmopterus baxteri, Centroselachus crepidater and all sharks (excludes chimaeras) pooled together were highly variable from one predator-prey combination to another (Table 3). All BMF were $>1$, indicating absolute biomagnifications (Hop et al. 2002). Higher BMF were generally observed between low trophic positions ( $\mathrm{TP}=2.0$ to 2.4 ) and shark species than those between secondary consumers ( $\mathrm{TP}=2.7$ to 3.5 ) and sharks (Table 3). For all predator-prey combinations higher BMF were observed in E. baxteri (mean $\mathrm{BMF}=63.8 \pm 30.5$ ) compared to adult $C$. crepidater $(33.9 \pm 16.0$, Table 3$)$.

Using the slope from the $\log (\mathrm{THg})$-TP regression model, TMF were calculated to provide relative rates of mean $\mathrm{THg}$ biomagnification through various assemblage or community food web organizations. Within the shark assemblage, moderate rates of biomagnification were observed; $\log (\mathrm{THg})\left(\mathrm{mg} \mathrm{kg}^{-1}\right.$, $\mathrm{wm})=0.20 \delta^{15} \mathrm{~N}-2.62=0.69 \mathrm{TP}-2.48 ; \mathrm{R}^{2}=0.47, \mathrm{p}<$ 0.05, with Centrophorus zeehaani at the highest trophic position, having the highest slope (highest Hg biomagnification rate) and Apristurus sinensis at the lowest trophic position (low biomagnification). When chimaeras and sharks were both included in the statistical calculations, lower biomagnification rates (slope $=0.13 \delta^{15} \mathrm{~N}=0.46 \mathrm{TP}$ ) and increased variability in the dataset $\left(R^{2}=0.20\right)$ were observed. Within the constraints of the limited sample size, both chimaera species showed significantly different rates of mercury biomagnification than the shark group $\left(F_{1,51}=5.74, \mathrm{p}=0.019\right)$ largely due their high trophic position (4.3), despite their relatively low THg levels (<1.0 mg kg-1, wm). Consequently, the TMF value calculated for the assemblage differed drastically depending whether chimaeras were included (2.84) or excluded (4.84) (Table 2).

Higher overall and mean rates of biomagnification rates (slope $=0.32 \delta^{15} \mathrm{~N}=1.13 \mathrm{TP} ; \mathrm{R}^{2}=0.78$ and $\mathrm{TMF}=13.3$ ) were observed in the extended continental (shelf and slope) community assemblage (spanning over $4.5 \mathrm{TP}$ ) than those for selected chondrichthyan assemblage (Table 2). However, among-system differences in TMF were observed between low-mid vs. mid-high order food chains and between shelf/upper-slope, mid-slope, and benthic food webs with much lower THg TMF in low-order (3.04) and in benthic (7.7) trophic assemblages (Table 2, Fig. 3). 


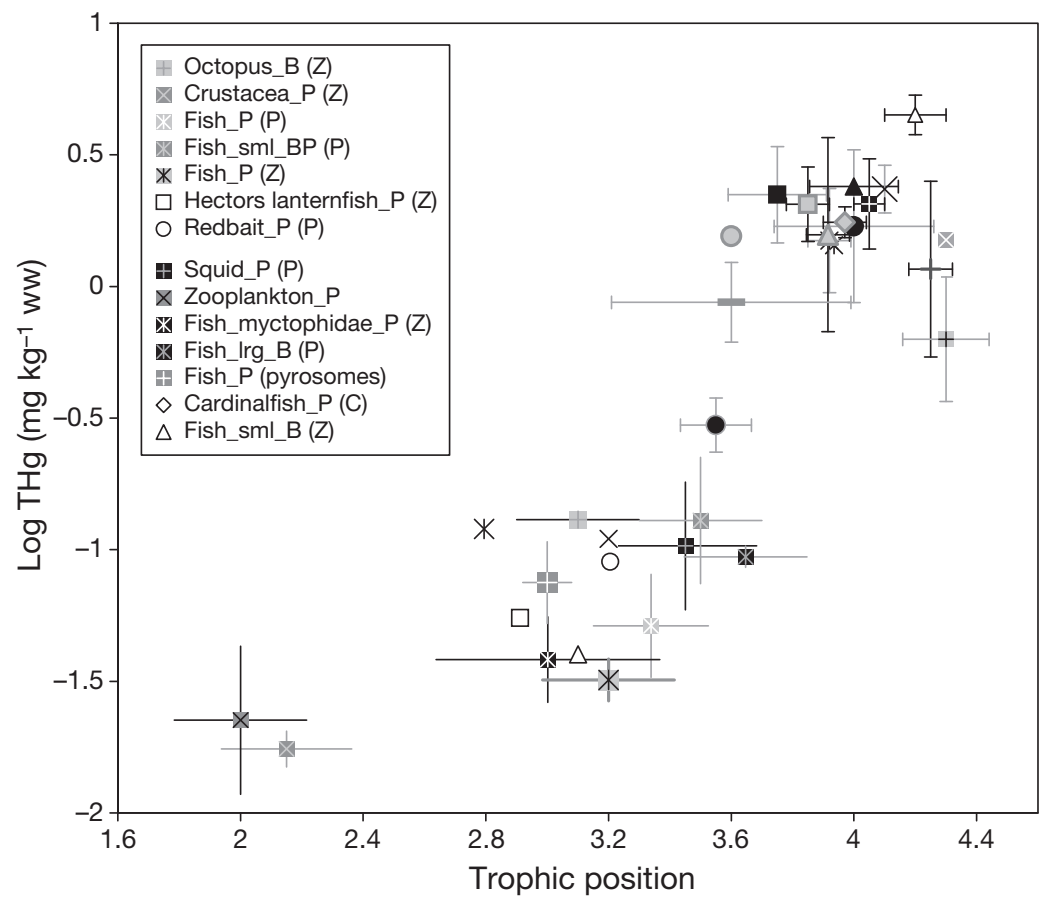

Fig. 3. Regression plot of total mercury (logTHg, $\mathrm{mg} \mathrm{kg}^{-1} \mathrm{wm}$ ) for selected trophic guild groups included in this study. Legend letters directly after prey names refer to habitat type: $\mathrm{B}=$ benthic $; \mathrm{P}=$ pelagic. $\mathrm{Sml}=$ small individuals; $\operatorname{lrg}=$ larger species, relative to the size of chondrichthyans. Letters in brackets refer to feeding mode: $\mathrm{P}=$ piscivores, $\mathrm{Z}=$ planktivores, $\mathrm{C}=$ crustacean specialist. Symbols for chondrichthyan assemblage as in Fig. 2
$13.3 \%$; thresher shark $13.5 \%$; Davenport \& Bax 2002), higher TP values were surprisingly observed in the demersal species reported in this study. Such a result may in part be explained by interspecific differences in white muscle enzyme activity and metabolic rates between shallow- and deep-living sharks (Treberg et al. 2003), which for fishes cannot be explained by differences in temperature or animal mass (Drazen \& Seibel 2007). Alternatively, as our study included several shelf-residing species (Squalus spp.) which showed limited difference in TP to other squaliforms, our result may in fact reflect differences in the length and/or complexity of associated food chains. A third hypothesis is that these shark species are indeed the apex predators in these environments; regularly feeding on higher-order marine mammals either by scavenging or, alternatively, by ambush-and-swim tactics as displayed by the cookie cutter shark. Indeed, Pethybridge et al. (2011) noted that several deepwater sharks including Proscymnodoms plunketi and Dalatias licha show strong intraguild predation values (and thus estimated TP) were observed in small catsharks and juvenile squaliformes, which have been found to be intermediate consumers of small squid and crustaceans (Pethybridge et al. 2011). In contrast, higher TP values were observed in squaliform species, which are well within the range of those previously reported (3.9 to 4.5; Cortés 1999, Bulman et al. 2002) and reflect a diet of mainly higher-order fish and squid (Graham \& Daley 2011, Pethybridge et al. 2011).

Using stomach content data and analysed by BrayCurtis dissimilarity indices, Bulman et al. (2002) explored the trophic guild structure of the mid-slope and seamount community off southern Tasmania (overlapping with our study area). They observed that TP ranged from 3.0 for pyrosome-feeders to 4.9 for piscivores and the overall average for the community was 3.7. In comparison, the majority of chondrichthyan species analysed in the present study, are clearly tertiary predators and reportedly higher than those for scavenging fish $(\mathrm{TP}=3.8)$, roughy's $(\mathrm{TP}=$ 4.1) and oreos ( $\mathrm{TP}=4.0)$ (Bulman et al. 2002). In comparison to $\delta^{15} \mathrm{~N}$ recorded in some pelagic sharks from continental shelf and pelagic waters slightly north of our study site (gummy shark 12.8\%; school shark
(IGP) interactions with several marine mammals.

Isotopic carbon $\left(\delta^{13} \mathrm{C}\right)$ signatures demonstrated a $2.2 \%$ difference and varied marginally within and between species, with the exception being Squalus acanthias (Table 1). Similar $\delta^{13} \mathrm{C}$ signatures have been recorded in demersal sharks (Domi et al. 2005), but differ from those reported in the Greenland shark Somniosus microphalus (Fisk et al. 2002) and pelagic sharks (Estrada et al. 2003, MacNeil et al. 2005), demonstrating the ability of $\delta^{13} \mathrm{C}$ to infer environmental differences in organic carbon sources. Most $\delta^{13} \mathrm{C}$ values reported in the present study were well within the range $(-20.6$ to $-14.6 \%$ ) found in a suite of bathypelagic fish collected in continental shelves of southeastern Australia (Davenport \& Bax 2002). The more depleted $\delta^{13} \mathrm{C}$ observed in $S$. acanthias $(-19.3 \%)$, is likely reflected in its more cosmopolitan distribution, typically occupying continental shelves and coastal waters at depths between surface waters and $1400 \mathrm{~m}$ (Last \& Stevens 2009). Davenport \& Bax (2002) found comparable $\delta^{13} \mathrm{C}$ values in the common dolphin Delphinus delphis and pilot whales Globicephala melas collected of southeastern Victoria, suggesting that these wide ranging animals feed in similar environments. 
Using a $\delta^{13} \mathrm{C}-\delta^{15} \mathrm{~N}$ biplot (Fig. 2A), we observed a highly overlapping matrix among conspecifics indicative of a large degree of dietary overlap and niche partitioning. However, for the 2 species with sufficient sample sizes, there was limited niche overlap (only $36 \%$ ), although similar isotope niche areas ( 0.8 to 1.1 units $^{2}$ ) were found between adult Etmopterus baxteri and Centroselachus crepidater; similarly C. crepidater showed no overlap between juveniles and adults. This clearly indicates ontogenetic shifts in dietary composition, which may be related to habitat affinity to some degree (due to quantifiable differences in $\delta^{13} \mathrm{C}$ ). Similar degrees of niche partitioning between these 2 species and evidence of ontogenetic dietary shift for C. crepidater were displayed by Pethybridge et al. (2011) using a combination of stomach content and signature fatty acid profile analysis and verifies the detection of inter- and intra-specific differences in resource (habitat and/or diet) use patterns.

\section{Trophic transfer and biomagnification of mercury}

Regression slopes, BMF and TMF each provide strong evidence for biomagnification of mercury in deepwater sharks and their associated ecosystems off southeastern Australian. Size (used as a proxy for age in intraspecific comparisons) was an important factor influencing both the trophic position (quantified by $\delta^{15} \mathrm{~N}$ values) and mercury biomagnification in individual species and within the entire chondrichthyes assemblage (Table 2). These findings are similar to those observed by numerous authors (Cabana \& Rasmussen 1994, Wiener et al. 2003, Domi et al. 2005) and confirm the phenomenon of biomagnification in which larger consumers typically feed at a higher trophic position, and thus acquire higher mercury loadings.

Ontogenetic diet and trophic status shifts in Centroselachus crepidater, as indicated by stable isotope analysis, were also accompanied by significantly different THg concentrations between small (juvenile) and large (adult) individuals. Similar ontogenetic studies have shown these patterns in C. crepidater (Hallett \& Daley 2011, Pethybridge et al. 2011), other sharks (i.e. Fisk et al. 2002), and other bathypelagic demersal species (McArthur et al. 2003) and are not surprising as changes in size are associated with aging until an asymptote is reached. Although few aging studies exist for most of the species examined, deep-water squaliformes have been shown to exhibit high longevity (Cailliet et al. 2006), with the age of some species (Centrophorus squamosus and Centrophorus zeehaani) found to be in excess of $46 \mathrm{yr}$ (Clarke et al. 2002, Irvine 2004). Consequently, it is likely that these species encounter slow and inefficient elimination of mercury over time.

Interspecific differences in mercury concentrations and BMF were observed between sympatric (midslope) squaliformes Etmopterus baxteri and Centroselachus crepidater, despite similar lengths for the 2 species. Such results are in agreement with the stable isotope findings in which $<41 \%$ overlap was observed, indicative of different feeding preferences for certain prey (dietary specialisation). Previous dietary studies for both species report a diverse mix of mesopelagic and bathypelagic fish and squid (Bulman et al. 2002, Daley et al. 2002). However, in a comparative dietary study by Pethybridge et al. (2011), small differences in diet composition seem evident with a slightly higher consumption of benthic and bathypelagic squid and fish in E. baxteri compared to C. crepidater. Several studies have demonstrated a general tendency for $\mathrm{THg}$ concentrations to be higher in benthic and deeper dwelling organisms than in pelagic species (Storelli et al. 2002, Choy et al. 2009). Equally apparent may be a greater consumption of invertebrates by C. crepidater in which large $\mathrm{THg}$ concentration differences have been reported for dominant invertivorous and piscivorous feeding sharks (de Pinho et al. 2002). However, for all prey species/groups included in this study, much higher and more variable BMF were observed in predator-prey relationships for E. baxteri $(76 \pm 29)$ than C. crepidater $(32 \pm 15)$ indicating interspecific differences in other biological (age structure and growth rates) or physiological (metabolic) traits associated with mercury biomagnification that are currently unknown.

Trophic magnification factors (TMF) are increasingly being used as a reliable and quantitative tool to assess and better understand contaminant bioaccumulation (Borgå et al. 2011). As indicated by the slope of the $\log \left(\mathrm{THg}\right.$ )-TP (quantified using $\delta^{15} \mathrm{~N}$ ) regression, the TMF obtained in the shark assemblage off southeastern Australia $\left(\delta^{15} \mathrm{~N}=0.20=\right.$ $0.69 \mathrm{TP} ; \mathrm{TMF}=4.84$, Table 2) and for all species including chimaeras $\left(\delta^{15} \mathrm{~N}=0.11=0.45 \mathrm{TP}\right.$; TMF $=$ 2.84) are within the range reported for other marine high-predator assemblages (Arctic seabirds: Jæger et al. 2009, Fish: Power et al. 2002). Within the constraints of our sample sizes, notably different trends in THg biomagnification rates between the sharks and chimaeras (Chimaera lignaria and Rhinochimaera pacifica) (Fig. 2B) are apparent, with the 
former displaying low $\mathrm{THg}$ concentrations relative to TP. We believe that this is primarily linked to between-group differences in (1) resource (diet and habitat) usage patterns, and/or (2) physiological (metabolic) divergence, which may be linked to THg elimination capabilities that are yet unknown.

Major differences in habitat and diet between the groups in this study have been reported previously. Chimaeras are principally benthic feeders of bivalves, polychaetes and crustaceans (Didier 2002). Catsharks are dominant pelagic squid consumers (Pethybridge et al. 2011). Squaliforms primarily feed on mesopelagic and bathypelagic fishes and squids (Bulman et al. 2002, Pethybridge et al. 2011). High $\delta^{15} \mathrm{~N}$ levels (TP) have been reported in other benthic feeding chimaeras (small-eyed rabbitfish Hydrolagus affinis) from the North Atlantic Ocean (Newman et al. 2011) and linked to variable but typically high TP values reported in carnivorous gastropod ( $\mathrm{TP}=2.8$ to 3.8 ) and polychaetes ( $\mathrm{TP}=3.4$ to 4.3 , Davenport \& Bax 2002). Clearly diet and habitat (food web and species composition) structure are largely responsible for the differences in mercury biomagnification rates between holocephalans and elasmobranchs, and among-system differences in calculated TMF (Table 2); however, the full implications remain unknown. To further examine THg transfer pathways in benthic systems, THg data on various infaunal and epibenthic organisms, along with greater sample sizes and more informed dietary information on these predators, are needed.

TMF calculations for the extended continental shelf and slope community food web (13.4) are higher than those typically reported (3.0 to 4.8 , using whole/muscle) in studies of whole ecosystems (Atwell et al. 1998, Campbell et al. 2005, Jæger et al. 2009). Such a finding may reflect a greater rate of mercury bioaccumulation in deep (>600 m) continental slope waters, as this is the first study (to the authors knowledge) to calculate $\mathrm{THg}$ magnification factors (TMF and BMF) in this environment. However, we found large TMF differences between lower (low to mid) and higher (mid to high) order mesopelagic food chains, indicating a rapid increase of biomagnification after its incorporation in midtrophic organisms (Fig. 3, Table 2). The TMF from low- to mid-food chain $\left(3.04, \mathrm{R}^{2}=0.57\right)$ is comparable to those found in other food web studies (Campbell et al. 2005, Jæger et al. 2009), but that between mid- to high-order predators seems far too high (28.8), despite the better fit to the dataset $\left(R^{2}=0.83\right)$. This clearly demonstrates that the relationship between THg and TP (and the ability of THg to be biotrans- formed) is not the same across all species and that biological properties (energy demands and growth, metabolic and biotransformation rates) need greater consideration in such regression models.

Age is known to confound TMF in systems containing mostly predators that are slow growing (Swanson \& Kidd 2010). Low sample sizes meant this effect could not be eliminated from our analysis. As turnover rates of isotopes represent a shorter timeinterval (weeks and months) than does mercury accumulation (years), THg elimination and biomagnification rates (and thus, TMF) would be greatly affected by the slow growth rates observed in these long-lived, deepwater sharks (Irvine 2004) compared to their fast-growing, short-lived counterparts. Other factors to consider are that we only studied muscle tissue THg concentrations in sharks, despite large loadings having been observed in the liver (Pethybridge et al. 2010b), whereas whole THg concentrations in prey were used. Lastly, although $\mathrm{THg}$ is a good proxy of MeHg in higher-order predators, the relative proportion of $\mathrm{MeHg}$ in $\mathrm{THg}$ only accounts for $\sim 15 \%$ in phytoplankton and $\sim 30 \%$ in zooplankton (Watras \& Bloom 1992), which would have an affect on THg vs. MeHg TMF calculations, due to increased transfer efficiencies of MeHg.

Regardless of the influences of age and other physiological factors, we report evidence of system differences with a much higher degrees of THg biomagnification shown to occur in deeper-dwelling, mid-slope species (16.8) compared to those primarily occurring in continental shelf and upper-slope waters (11.0). This finding is in agreement with that of Choy et al. (2009), who demonstrated that THg loadings of predatory fishes and their prey increase with median vertical distribution in the water column. Monteiro et al. (1996) also found that total $\mathrm{Hg}$ concentrations in the subtropical Atlantic increased 4-fold from epipelagic (surface $<200 \mathrm{~m}$ ) to mesopelagic (continental shelf $>300 \mathrm{~m}$ ) fish species. Not surprisingly, our findings also correspond to the vertical profile of $\mathrm{MeHg}$ in waters off southeastern Australia, in which Cossa et al. (2011) reported higher $\mathrm{MeHg}$ in deeper (650$1200 \mathrm{~m})$ compared to shallower $(200-650 \mathrm{~m})$ continental slope waters. Furthermore, the proportion of THg as MeHg have also been shown to differ substantially between surface waters $(5 \%)$ and deep waters below $1000 \mathrm{~m} \mathrm{(50 \% )} \mathrm{(Cossa} \mathrm{et} \mathrm{al.} \mathrm{2011).} \mathrm{Thus}$ it seems evident that the among-system differences found in the present study are largely explained by the physical-chemical (related to bathome distribution) and community (species composition and food chain length) structure. 
Our study presents new information on trophic definition and mercury biomagnification in rarely studied species and environments. Nonetheless, as noted throughout this paper, considerable variability remains unexplained. Much of this uncertainty could be reduced through (1) greater sample sizes and inclusion of more diverse prey taxa, (2) the establishment of baseline $\delta^{13} \mathrm{C}$ or $\delta^{15} \mathrm{~N}$, and (3) quantifying the effect of age, because long-lived predators comprise a major proportion of the biomass in these deepwater systems. If these improvements were achieved, mercury sources and transfer processes in deepwater food webs could be identified through the utilization of ecosystem based models.

Acknowledgements. We thank B. Averty and S. Guedron for their assistance with mercury analyses. Thanks are also expressed to the captain and crew of the 'Adriatic Pearl' and other commercial fishing boats for sample collection. We thank 4 anonymous referees for their constructive comments that helped improve earlier versions of this manuscript. This project was partly funded by a Goddard Sapin-Jaloustre Trust Fund grant to H.P.

\section{LITERATURE CITED}

> Atwell L, Hobson KA, Welch HE (1998) Biomagnification and bioaccumulation of mercury in an Artic food web: insights from stable nitrogen isotopes analysis. Can J Fish Aquat Sci 55:1114-1121

> Borgå K, Kidd K, Berglund O, Conder JM and others (2011) Trophic magnification factors: impact of ecology, ecosystem and study design. Integrated Environ Assess Manag 8:64-84

Bulman CM, He X, Koslow JA (2002) Trophic ecology of the mid-slope demersal fish community off southern Tasmania, Australia. Mar Freshw Res 53:59-72

> Burger J, Gochfeld M, Shukla T, Jeitner C and others (2007) Heavy metals in Pacific cod (Gadus macrocephalus) from the Aleutians: location, age, size, and risk. J Toxicol Environ Health A 70:1897-1911

Cabana G, Rasmussen JB (1994) Modelling food chain structure and contaminant bioaccumulation using stable Nisotopes. Nature 372:255-257

> Cailliet GM, Smith WD, Mollet HF, Goldman KJ (2006) Age and growth studies of chondrichthyan fishes: the need for consistency in terminology, verification, validation, and growth function fitting. Environ Biol Fishes 77: 211-228

> Campbell LM, Norstrom RJ, Hobson KA, Muir DCG, Backus S, Fisk AT (2005) Mercury and other trace elements in a pelagic Arctic marine food web (Northwater Polynya, Baffin Bay). Sci Total Environ 351-352:247-263

Choy CA, Popp B, Kaneko J, Drazen J (2009) The influence of depth on mercury levels in pelagic fishes and their prey. Proc Natl Acad Sci USA 106:13865-13869

Clarke MW, Connolly PL, Bracken JJ (2002) Age estimation of the exploited deepwater shark Centrophorus squamosus from the continental slopes of the Rockall Trough and Porcupine Bank. J Fish Biol 60:501-514
Cortés E (1999) Standardized diet compositions and trophic levels of sharks. ICES J Mar Sci 56:707-717

Cossa D, Coquery M, Nahklé K, Claisse D (2002) Dosage du mercure total and du monométhylmercury dans les organismes et les sédiments marins. Méthodes d'analyse en milieu marin. Editions Ifremer, Plouzané

Cossa D, Heimbürger LE, Lannuzel D, Rintoul SR and others (2011) Mercury in the Southern Ocean. Geochim Cosmochim Acta 75:4037-4052

Daley R, Stevens J, Graham A (2002) Catch analysis and productivity of the deepwater dogfish resources in southern Australia. FRDC Project 1998/108. CSIRO Marine Research, Hobart

> Davenport S, Bax N (2002) A trophic study of a marine ecosystem off south eastern Australia using stable isotopes of carbon and nitrogen. Can J Fish Aquat Sci 59: 514-530

$>$ de Pinho AP, Guimarães JRD, Martins AS, Costa PAS, Olavo G, Valentin J (2002) Total mercury in muscle tissue of five shark species from Brazilian offshore waters: effects of feeding habit, sex, and length. Environ Res 89:250-258

Didier DA (2002) Chimaeras. In: Carpenter KE (ed) The living marine resources of the Western Central Atlantic. FAO, Rome, p 592-599

> Domi N, Bouquegneau JM, Das K (2005) Feeding ecology of five commercial shark species of the Celtic Sea through stable isotope and trace metal analysis. Mar Environ Res 60:551-569

> Drazen JC, Seibel BA (2007) Depth-related trends in metabolism of benthic and benthopelagic deep-sea fishes. Limnol Oceanogr 52:2306-2316

Drazen JC, Popp BN, Choy AC, Clemente T, De Forest L, Smith KL Jr (2008) Bypassing the abyssal benthic food web: macrourid diet in the eastern North Pacific inferred from stomach content and stable isotopes analyses. Limnol Oceanogr 53:2644-2654

> Ebert DA, Compagno LJV, Cowley PD (1992) A preliminary investigation of the feeding ecology of squaloid sharks off the west coast of southern Africa. S Afr J Mar Sci 12: 601-609

Eisler R (2006) Mercury hazards to living organisms. CRC Press, Boca Raton, FL

Estrada JA, Rice AN, Lutcavage ME, Skomal GB (2003) Predicting trophic position in sharks of the North-west Atlantic Ocean using stable isotope analysis. J Mar Biol Assoc UK 83:1347-1350

Fisk AT, Tittlemier SA, Pranschke JL, Norstrom RJ (2002) Using anthropogenic contaminants and stable isotopes assess the feeding ecology of Greenland sharks. Ecology 83:2162-2172

Fry B, Sherr EB (1984) $\delta^{13} \mathrm{C}$ measurements as indicators of carbon flow in marine and freshwater ecosystems. Contrib Mar Sci 27:13-47

Graham KJ, Daley RK (2011) Distribution, reproduction and population structure of three gulper sharks (Centrophorus, Centrophoridae) in south-east Australian waters. Mar Freshw Res 62:583-595

> Graham KJ, Andrew NL, Hodgson KE (2001) Changes in relative abundance of sharks and rays on Austalian South East Fishery trawl grounds after twenty years of fishing. Mar Freshw Res 52:549-561

Hallett CS, Daley RK (2011) Feeding ecology of the southern lanternshark (Etmopterus baxteri) and the brown lanternshark (E. unicolor) off southeastern Australia. ICES J Mar Sci 68:157-165 
Hobson KA (1999) Tracing origins and migration of wildlife using stable isotopes: a review. Oecologia 120:314-326

Hobson KA, Piatt JF, Pitocchelli J (1994) Using stable isotopes to determine seabird trophic relationships. J Anim Ecol 63:786-798

Hobson KA, Ambrose WG, Renaud PE (1995) Sources of primary production, benthic-pelagic coupling, and trophic relationships within the Northeast water polynya: insights from $\delta^{13} \mathrm{C}$ and $\delta^{15} \mathrm{~N}$ analysis. Mar Ecol Prog Ser 128:1-10

Hoffman JC, Sutton TT (2010) Lipid correction for carbon stable isotope analysis of deep-sea fishes. Deep-Sea Res I 57:956-964

Hop H, Borgå K, Gabrielsen GW, Kleivane L, Skaare JU (2002) Food web magnification of persistent organic pollutants in poikilotherms and homeotherms from the Barents Sea. Environ Sci Technol 36:2589-2597

Irvine SB (2004) Age, growth and reproduction of deepwater dogfishes from southeastern Australia. $\mathrm{PhD}$ thesis, Deakin University Warrnambool, Victoria

Jæger I, Hop H, Gabrielsen GW (2009) Biomagnification of mercury in selected species from an Arctic marine food web in Svalbard. Sci Total Environ 407:4744-4751

Kyne PM, Simpfendorfer CA (2010). Deepwater chondrichthyans. In: Carrier JC, Musick JA, Heithaus MR (eds) The biology of sharks and their relatives, Vol 2. CRC Press, Boca Raton, FL, p 37-113

Larcombe J, Begg G (2007) Fishery Status Reports 2007; Status of fish stocks managed by the Australian Government. Australian Government, Bureau of Rural Sciences, Department of Agriculture, Fisheries and Forestry

Last PR, Stevens JD (2009) Sharks and rays of Australia. CSIRO Publishing, Melbourne

Lesage V, Hammil MO, Kovacs KM (2001) Marine mammals and the community structure of the Estuary and Gulf of St Lawrence, Canada: evidence from stable isotope analysis. Mar Ecol Prog Ser 210:203-221

MacNeil MA, Skomal GB, Fisk AT (2005) Stable isotopes from multiple tissues reveal diet switching in sharks. Mar Ecol Prog Ser 302:199-206

Mason RP, Reinfelder JR, Morel FMM (1995) Bioaccumulation of mercury and methylmercury. Water Air Soil Pollut 80:915-921

McArthur T, Butler ECV, Jackson JD (2003) Mercury in the marine food chain in the Southern Ocean at Macquarie Island: an analysis of a top predator, Patagonian toothfish (Dissostichus eleginoides) and a mid-trophic species, the warty squid (Moroteuthis ingens). Polar Biol 27:1-5

Minagawa M, Wada E (1984) Stepwise enrichment of $\delta^{15} \mathrm{~N}$ along food chains: further evidence and the relation between $\delta^{15} \mathrm{~N}$ and animal age. Geochim Cosmochim Acta 48:1135-1140

> Monteiro LR, Costa V, Furness RW, Santos RS (1996) Mercury concentrations in prey fish indicate enhanced bioaccumulation in mesopelagic environments. Mar Ecol Prog Ser 141:21-25

Editorial responsibility: Matthias Seaman, Oldendorf/Luhe, Germany
Newman MC, Xu X, Cotton CF, Tom KR (2011) High mercury concentrations reflect trophic ecology of three deep-water chondrichthyans. Arch Environ Contam Toxicol 60:618-625

> Peterson BJ, Fry B (1987) Stable isotopes in ecosystem studies. Annu Rev Ecol Syst 18:293-320

> Pethybridge H, Cossa D, Butler ECV (2010a) Mercury in 16 demersal sharks from southeast Australia: biotic and abiotic sources of variation and consumer health implications. Mar Environ Res 69:18-26

Pethybridge H, Nichols P, Virtue P (2010b) Lipid composition and partitioning of deepwater chondrichthyans: inferences of feeding ecology and distribution. Mar Biol 157:1367-1384

Pethybridge H, Daley R, Virtue P, Butler ECV, Cossa D, Nichols PD (2010c) Lipid and mercury profiles of 61 midtrophic species collected off south-eastern Australia. Mar Freshw Res 61:1092-1108

Pethybridge H, Daley R, Nichols PD (2011) Diet of demersal sharks and chimaeras inferred by fatty acid profiles and stomach content analysis. J Exp Mar Biol Ecol 409: 290-299

> Post DM (2002) Using stable isotopes to estimate trophic position: models, methods and assumptions. Ecology 83: 703-718

> Power M, Klein GM, Guiguer KRRA, Kwan MKH (2002) Mercury accumulation in the fish community of a subArctic lake in relation to trophic position and carbon sources. J Appl Ecol 39:819-830

Selin NE (2011) Science and strategies to reduce mercury risks: a critical review. J Environ Monit 13:2389-2399

Storelli MM, Giacominelli Stuffler R, Marcotrigiano GO (2002) Total and methylmercury residues in tuna-fish from Mediterranean sea. Food Addit Contam 19: $715-720$

> Swanson HK, Kidd KA (2010) Mercury concentrations in Arctic food fishes reflect presence of anadromous Arctic charr (Salvelinus alpinus), species, and life history. Environ Sci Technol 44:3286-3292

> Treberg JR, Martin RA, Driedzic WR (2003) Muscle enzyme activities in a deep-sea squaloid shark, Centroscyllium fabricii, compared with its shallow-living relative, Squalus acanthias. J Exp Zool A 300:133-139

Vaudo JJ, Heithaus MR (2011) Dietary niche overlap in a nearshore elasmobranch mesopredator community. Mar Ecol Prog Ser 425:247-260

> Wang WX (2002) Interactions of trace metals and different marine food chains. Mar Ecol Prog Ser 243:295-309

Watras CJ, Bloom NS (1992) Mercury and methylmercury in individual zooplankton: implications for bioaccumulation. Limnol Oceanogr 37:1313-1318

Wiener JG, Krabbenhoft DP, Heinz GH, Scheuhammer AM (2003) Ecotoxicology of mercury. In: Hoffman DH, Rattner BA, Burton AG, Cairns J (eds) Handbook of ecotoxicology, 2nd edn. CRC Press, Boca Raton, FL, p 409-463

Submitted: August 3, 2011; Accepted: January 6, 2012

Proofs received from author(s): March 23, 2012 